\title{
Lord Walton of Detchant: There and Back Again
}

\author{
Patrick F. Chinnery* \\ Director of the Institute of Genetic Medicine, Newcastle University \& Newcastle upon Tyne Hospitals NHS \\ Foundation Trust, London, UK
}

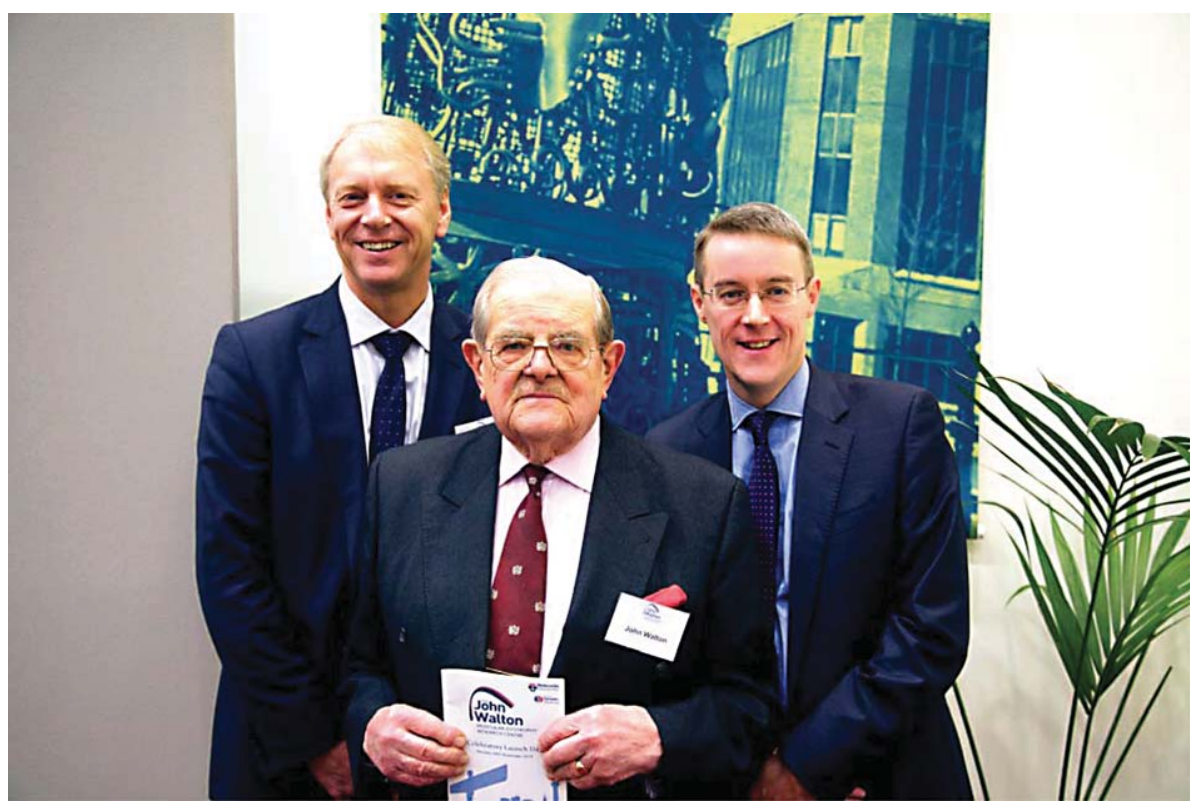

Fig. 1. Lord Walton (middle) with Professor Chris Day (Pro-Vice-Chancellor, Faculty of Medical Sciences, Newcastle University, left) and Professor Patrick Chinnery (Director Institute of Genetic Medicine, Newcastle University, right) during the launch of The Newcastle University John Walton Muscular Dystrophy Research Centre on November 24, 2014.

This special edition of the Journal of Neuromuscular Diseases marks the inauguration of the John Walton Centre for Neuromuscular Diseases at Newcastle University in the north east of England on the 24th November 2014. The Institute of Genetic Medicine hosted the event which brought together world leaders in the field of neuromuscular disorders - both past

\footnotetext{
*Correspondence to: Patrick F. Chinnery, Director of the Institute of Genetic Medicine, Newcastle University \& Newcastle upon Tyne Hospitals NHS Foundation Trust, London, UK. Tel.: +44 191 8663; E-mail: patrick.chinnery@ncl.ac.uk.
}

and present - to celebrate the remarkable and on-going contribution made by Lord Walton of Detchant to the field of neuromuscular disorders, from his early work as a junior researcher in Newcastle upon Tyne over 50 years ago, through to his pivotal role in the UK Parliament.

The following articles describe the recent ground breaking scientific discoveries in the field of neuromuscular diseases that were presented at the International Centre for Life less than 10 miles from Rowlands Gill, the place where John Nicholas Walton was born in 1922. At the time, his father was a headmaster of 

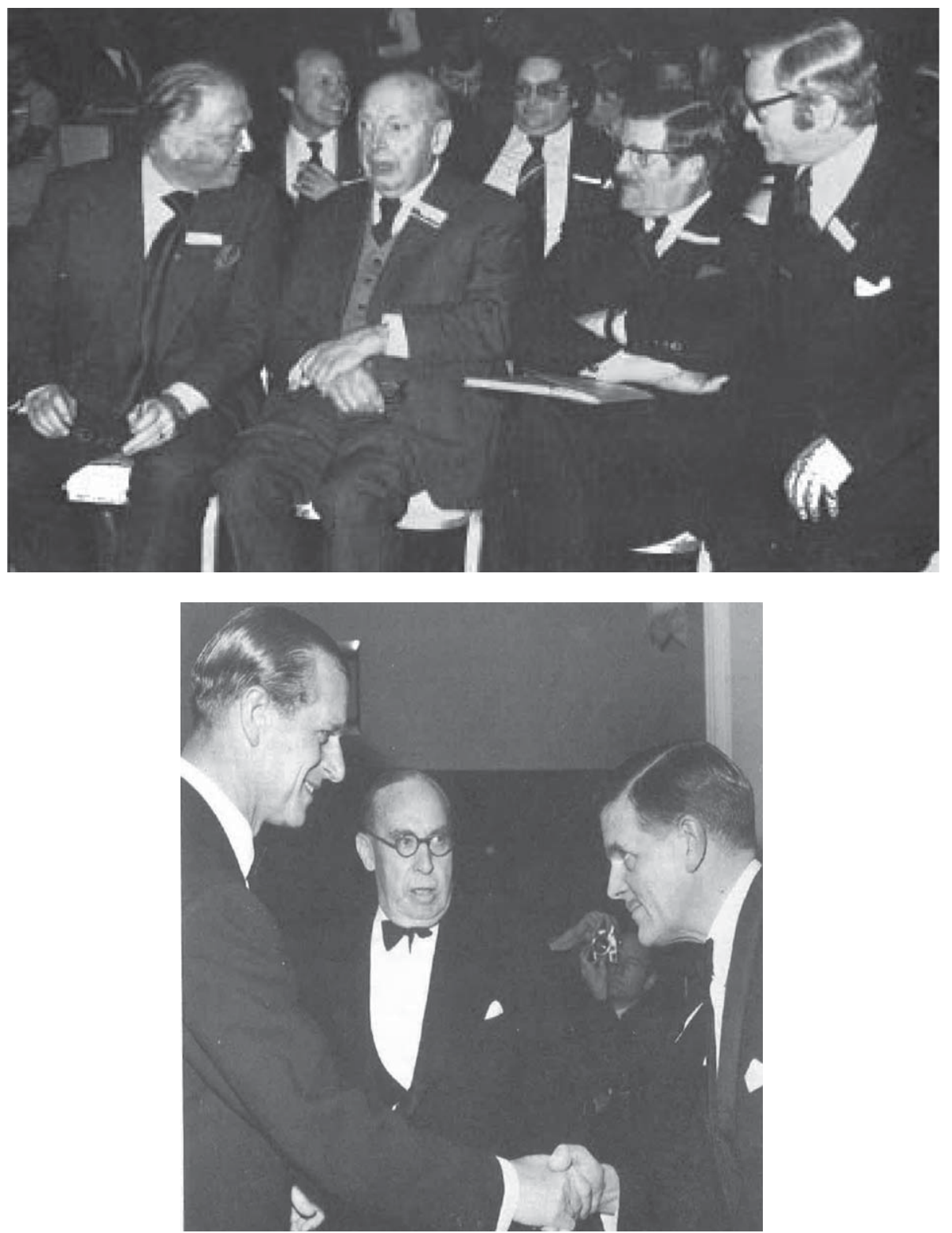

Fig. 2. (upper panel, from left): Richard Attenborough (later Lord Attenborough of Richmond upon Thames), Professor F.J. Nattrass (former Professor of Medicine at University of Newcastle), John Walton and Paul Walker (Executive Director of the Muscular Dystrophy Group as Muscular Dystrophy UK was then known). (lower panel, from left): His Royal Highness Prince Philip, Duke of Edinburgh, Lord Heyworth, who for a brief period was Chairman of the Muscular Dystrophy Group, and John Walton.

Middlestone Moor Primary School, before a promotion led the family to move to the north Durham coalmining community of Spennymoor. There John spent much of his childhood whilst attending Alderman Wraith Grammar School. Having secured a place as a medical student in 1941, the Royal Air Force turned down his application to serve King and Country in combat, realising the critical contribution new doctors would make to the war effort. John therefore made the short trip to Newcastle, where the medical school was part of King's College, University of Durham. He qualified in medicine in 1945, working initially as House Officer to Professor Nattrass, and then Professor James Spence. Remarkably, his annual salary doubled between the first and second year as a junior doctor - from $£ 50$ to $£ 100$. 


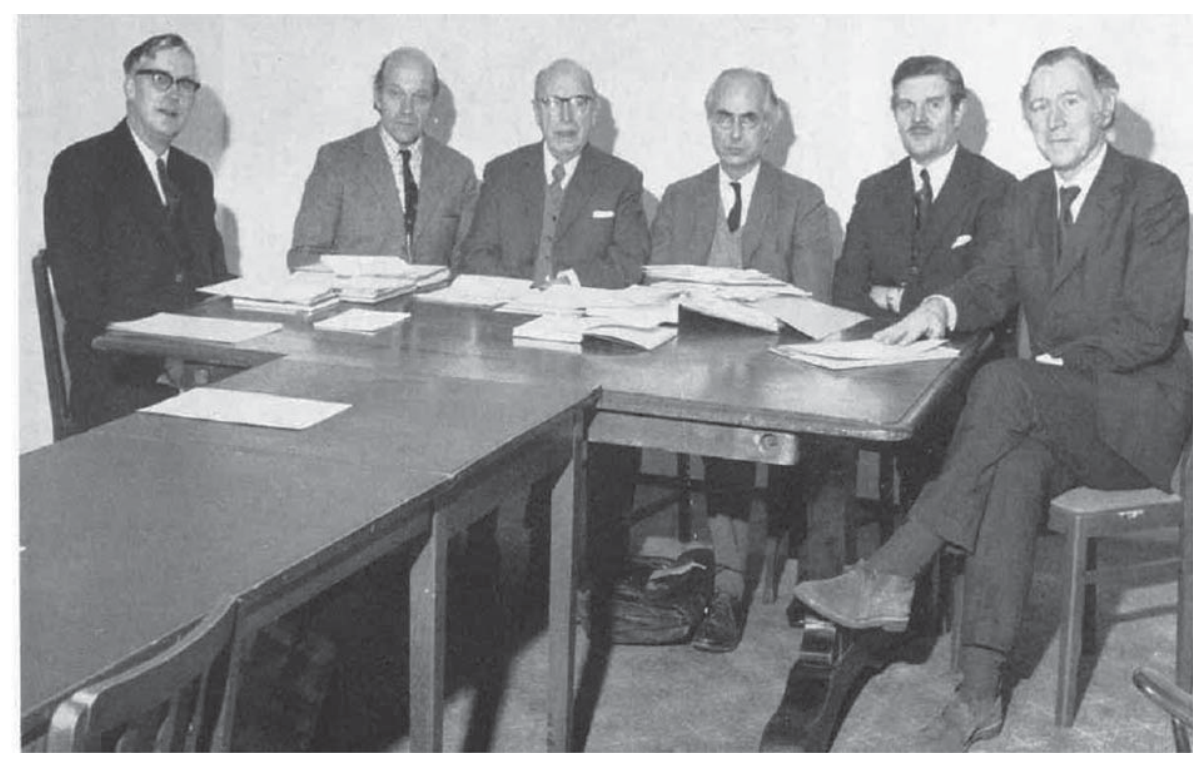

Fig. 3. The Research Committee of the Muscular Dystrophy Group with - from the left - Professor Joe Smith (Birmingham), Professor Ian Simpson (Glasgow), Professor Fred Nattrass, Professor Sir Andrew Huxley (a Nobel Laureate and Chairman of the Committee), John Walton and Professor Victor Perry..

Called for military service in 1947, Dr Walton was the Embarkation Medical Officer in Glasgow and later in Southampton, before becoming Second-inCommand of the Hospital Ship Oxfordshire. During that time he visited many Mediterranean ports and was involved in the final evacuation of Haifa Military Hospital and of British troops leaving Palestine in 1948. His interest in neuromuscular research began in 1950s, again working with Fred Nattrass he published the landmark classification of neuromuscular diseases in the journal Brain [1]. In this way Dr Walton became one of the founding fathers of modern myology, and he established a model of continuously improving his clinical practice through scientific enquiry. Now commonplace, this model had its foundations in the careful clinical observation of patients followed by appropriate clinical investigations, which often involved a muscle biopsy analysed by the clinician in adjacent laboratories. As a Consultant Neurologist, he documented the inheritance pattern of different phenotypes which laid the foundations for future genetic linkage, exome and whole genome studies, paving the way for gene-based therapies for muscular dystrophies.

His ethos permeated the national neurology scene, in no small part through his central role developing regional neurology services throughout the United Kingdom. In 1958, and only two miles from the recent inaugural event, he established the first Regional Neurosciences Centre in the North of England. Integrating the clinical service with neuromuscular research laboratories, this became an international hub for trainees in the field of neuromuscular diseases. Many past pupils of John Walton were present at the symposium in 2014, travelling from all four corners of the globe. After a period of time studying with him in Newcastle in the 1950s and 1960s, they returned to their homelands and established neuromuscular centres in the image of the Newcastle unit. Many of these centres have gone from strength to strength, and underpin global efforts to develop new treatments for inherited and acquired neuromuscular diseases.

In recent years, patients have taken an increasingly prominent role in the design and implementation of translational research programmes. Junior colleagues may think that this is an innovation, but nothing could be further from the truth, and Professor John Walton was one of the early stalwarts. Back in the 1950s he co-founded the Muscular Dystrophy Campaign (now Muscular Dystrophy UK), of which he is now Honorary Life President. In those early days he realised that harnessing "patient power" to set the research agenda provided the most powerful influence, ensuring that the patients needs were at the centre of any disease-based research, and encouraging investment in clinical research from the Government 

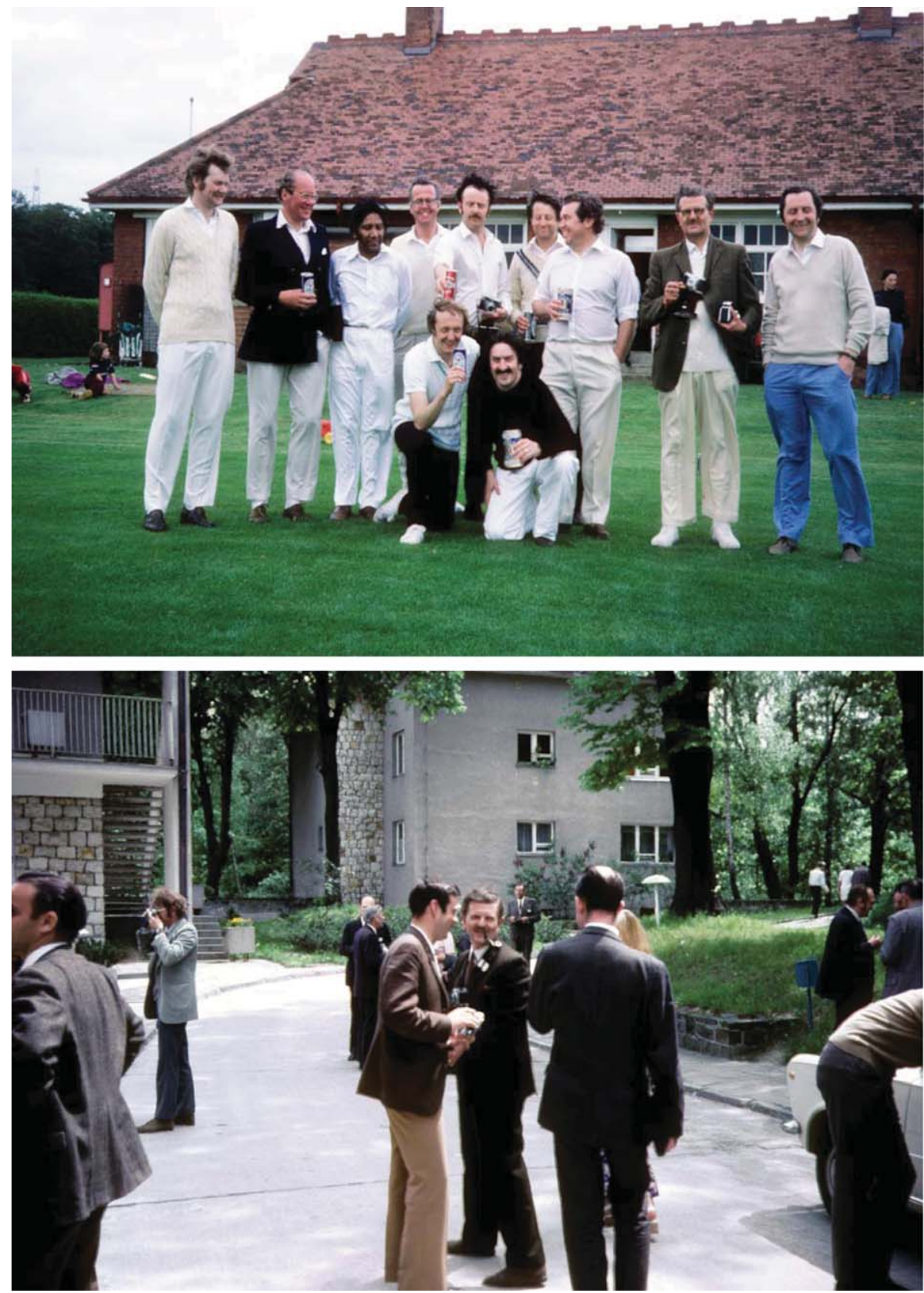

Fig. 4. (upper panel): Annual retreat and cricket match at Close House around 1970 showing (back row, from left) NN, Jack Foster, Anil Desai, David Barwick, Peter Tilley, David Gardner-Medwin, Peter Hudgson, John Walton, NN. Kneeling at the front Russell Lane and Dr al-Jishi. (lower panel): Erik Stalberg, John Walton, back view of Alan McComas.

and the charity sector. It is difficult to over-emphasize the important role that John Walton played in all these areas.

Whilst charting new clinical and pathological phenotypes, he spent 10 years as Dean of the Newcastle Medical School from 1971-1981 and increasingly played a key part in the development of British medicine through his roles as President of the General Medical Council, member of the Medical Research Council, the British Medical Association and the Royal Society of Medicine. His adept persuasive skills and solid chairmanship led to similar success on the international stage as President of the World Federation of Neurology and other organisations. As a consequence 


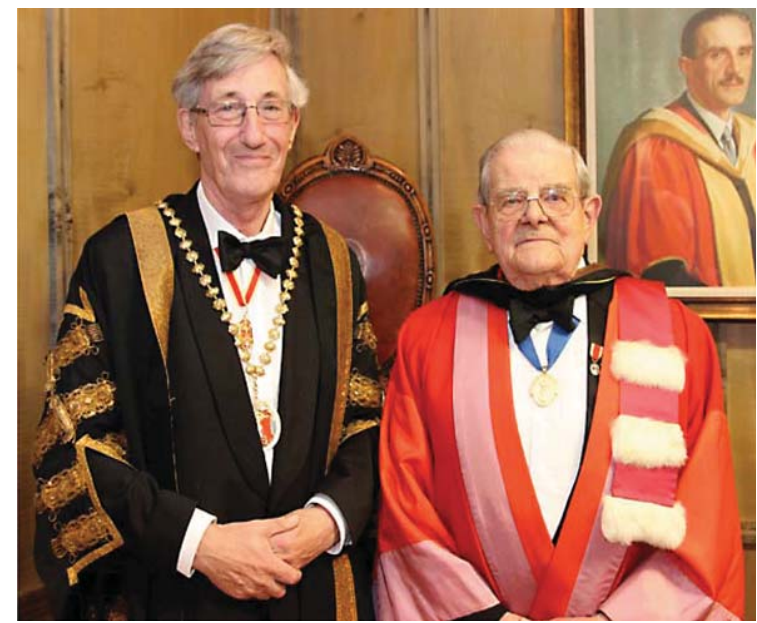

Fig. 5. Professor Sir Michael Rawlins (Ruth and Lionel Jacobson Professor of Clinical Pharmacology at the University of Newcastle, President of the Royal Society of Medicine) presenting John Walton with the RSM Medal in 2004.

he was knighted by Queen Elizabeth II in 1979 for his services to medicine.

With his children having left home, and spending increasingly large amounts of time addressing national and international issues, it became clear to his late wife Betty that John was spending more time away from the North East of England than he was here. They therefore moved to Green College, Oxford, where he served as
Warden from 1983 until 1989. That same year he was made a life peer, and Baron Walton of Detchant took up his place in the House of Lords where he continues to sit as a cross-bencher (i.e. with no political affiliation) [2]. In 1992 he became a member of the Science and Technology Committee, leaving in 1996 and returning again in 1997. From 1993 he was Chair of the Medical Ethics Committee, and since 2009 has been Secretary of the Rare Disease Group. He made a significant contribution to the Lords debate on mitochondrial transfer, of which he has been a strong supporter, and he has also been outspoken on end of life issues that have recently been in the public eye. Now aged 92 years, Lord Walton remains highly active in the Upper House of Parliament providing both clinical and scientific advice to the UK Government [2]. This short introduction fails to touch on many of the key achievements of Lord Walton, many of which are outlined in his autobiography, The Spice of Life [3]. Charting his life events from his early years in Durham County through to his ennoblement in the House of Lords in 1989, this can only be considered the first volume of his memoires, because he has remained so active since that time. His razor sharp inquiring mind has ensured that his medical and scientific knowledge is always up to date, enabling an informed contribution to the national debate, and, as I am witness, to some insightful questioning at international scientific meetings. But despite his very active international profile, his heart has remained in the north east of England,

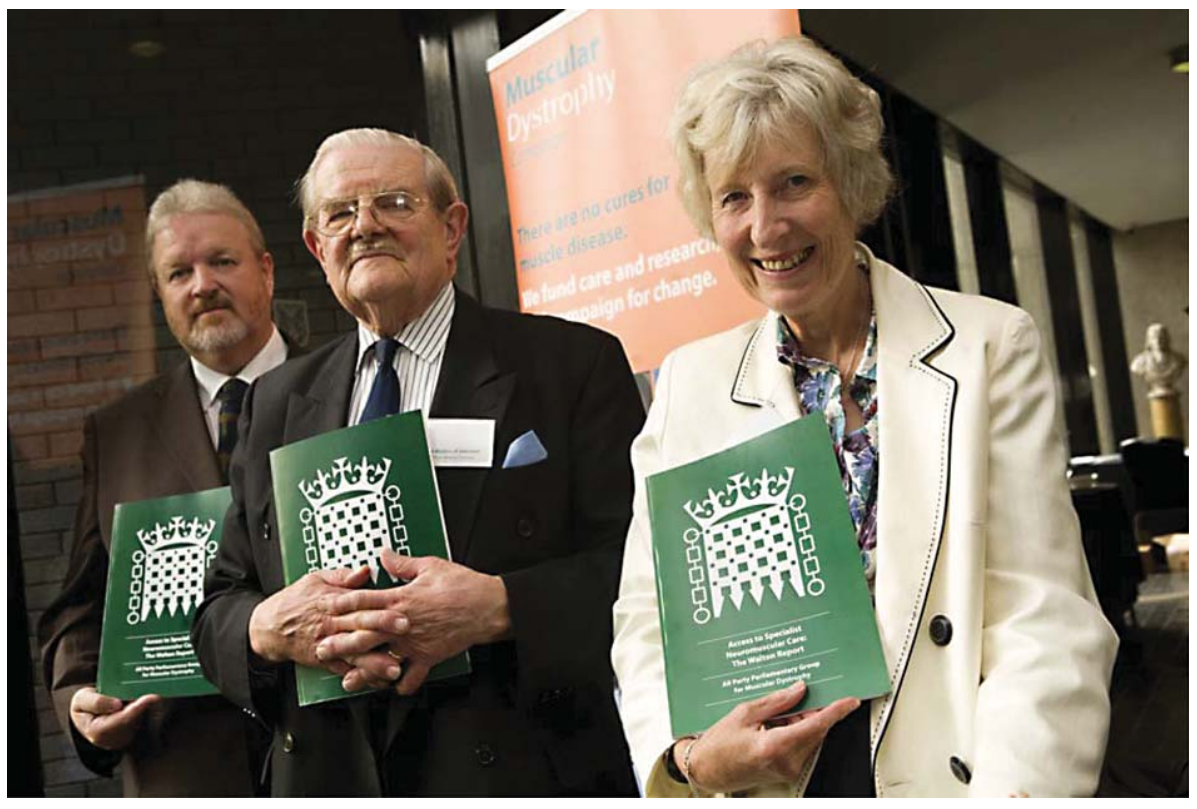

Fig. 6. Launching the Walton Report on 24 August 2009 - Dave Anderson Member of Parliament (Chair of All Party Parliamentary Group), John Walton and Baroness Celia Thomas (Vice Chair). 


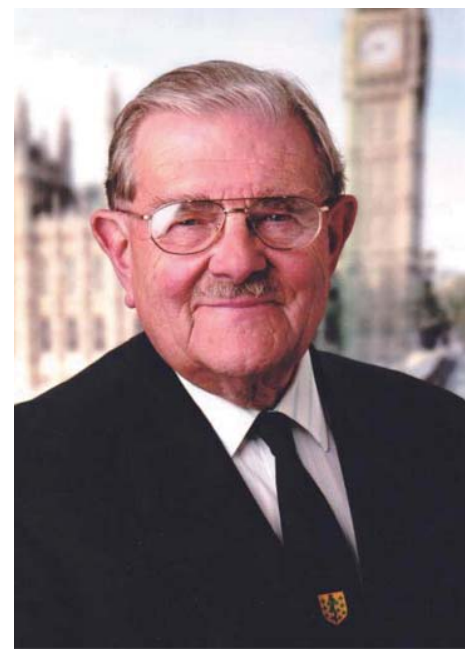

where he returned from 'there and back again' in 2002 - only this time to a restored piggery at Belford in 2002 close to the North Sea coast. Passing the family home on to one of his children, he now lives just down the road. This is a short drive from Berwick railway station, enabling weekly trips via the east coast main line to the House of Lords where he remains actively engaged to this day [2].

As Director of the Institute of Genetic Medicine at Newcastle University and as a clinical neurologist who has worked in the neuromuscular field for 20 years, I am honoured to provide this brief overview. I am in no doubt that naming the Newcastle Neuromuscular Centre after John Walton will serve as an inspiration for current and future researchers to continue along his path, and improve the lives of patients and families affected by neuromuscular disease.

\section{REFERENCES}

[1] Walton JN, Nattrass FJ. On the classification, natural history and treatment of the myopathies. Brain. 1954;77(2):169-231.

[2] http://www.publications.parliament.uk/pa/ld201415/ldhansrd/ ldallfiles/peers/ lord_hansard_4515_home.html

[3] Walton JN. The Spice of Life: From Northumbria to World Neurology. 1993, Royal Society of Medicine, London. 